\title{
PERBAIKAN SIFAT FISIKO-KIMIA TANAH PSAMMENT DENGAN PEMULSAAN ORGANIK DAN OLAH TANAH KONSERVASI PADA BUDIDAYA J AGUNG
}

\author{
Adrinal $^{1}$, Amrizal Saidi, dan Gusmini \\ ${ }^{1}$ Jurusan Tanah Fakultas Pertanian Universitas Andalas \\ E-mail : adrinal81@yahoo.com
}

\begin{abstract}
A research about amelioration of psycho-chemical of Psamment by using organic mulch and techniques of conservation tillage on corn growth had been conducted in 2009. Field experiment was located in Korong Olo Bangau, Batang Anai, Padang Pariaman Regency. The general objective of the research was to improve fertility of Psamment and to find out the best tillage practice for corn growth based on soil and water conservation rules. The treatment consisted of two factors $(3 \times 5)$ which was designed in RBD. The first factor was tillage (No till, Minimum till, convensional till) and the second factor was mulch source (without mulch, Tithonia, Chromolaena, rice straw, and corn straw). Parameters analysed were either soil physical (moisture, $\mathrm{BD}$, total pore, aggregation) or chemical $(\mathrm{pH}, \mathrm{N}, \mathrm{P}$, and $\mathrm{K}$ ) properties, as well as crop production. The result showed that both treatments were able to improve soilphysico-chemical properties of Psamment and corn yield. The value of BD decreased, soil organic mattere, total pore, and aggregation increased. Then, the soil $\mathrm{pH}$ as well as available $\mathrm{P}$ and $\mathrm{K}$ tended to increase. The highest yield (dry seeds) was found from combination between minimum tillage and tithonia mulch.
\end{abstract}

Keywords: sifat fisiko-kimia, P samment, mulksa, olah tanah konservasi, jagung.

\section{PENDAHULUAN}

Pengolahan tanah konservasi adalah setiap bentuk pengolahan tanah dan sistem penanaman yang menutupi $30 \%$ atau lebih permukaan tanah dengan sisa tanaman, setelah proses penanaman untuk mengurangi erosi tanah oleh air. Berbagai penelitian (Suwardjo et al, 1989; Brown et al 1991; Wagger dan Detton, 1991; Adrinal dan Armon, 1993; Adrinal, 1998) melaporkan bahwa olah tanah konservasi merupakan alternatif penyiapan lahan yang dapat mempertahankan produktivitas tanah tetap tinggi

Beberapa cara pengolahan tanah yang memenuhi kriteria sebagai olah tanah konservasi (OTK) diantaranya adalah tanpa olah tanah (zerro tillage), olah tanah seperlunya (reduced tillage) dan olah tanah strip (strip tillage). Aplikasi dari ketiga jenis OTK tersebut harus selalu disertai dengan penggunaan mulsa organik.
Menurut Rachman et al, (2004), hal yang menentukan keberhasilan OTK adalah pemberian bahan organik dalam bentuk mulsa yang cukup. Mulsa dapat menekan pertumbuhan gulma, menekan laju kehilangan air, dan laju pemadatan tanah. Sisi lain dari penerapan OTK adalah karena juga dapat menghemat tenaga kerja (Dariah, 2007).

Jerami padi dan jerami jagung merupakan sisa hasil panen dan sumber bahan organik yang ketersediaannya cukup melimpah setelah kegiatan panen dilakukan. Pengembalian sisa tanaman ini ke lahan usaha tani akan memberikan manfaat ganda dalam usaha konservasi dan peningkatan status kesuburan tanah. Penggunaannya sebagai mulsa yang dihamparkan di atas lahan yang ditanami tanaman budidaya akan melindungi tanah dari daya perusak hujan dan alisan permukaan, disisi lain dengan berjalannya waktu dan terjadinya dekomposisi bahan organiknya akan 
menyumbangkan unsur hara kepada tanah dimana bahan tersebut dihamparkan

Salah satu tumbuhan yang cukup berpotensi untuk dijadikan mulsa dan pupuk hijau adalah tithonia (Tithonia diversivolia) atau yang dikenal dengan nama bunga matahari Meksiko (Mexican sun flower) karena dapat tumbuh di sembarang tempat (Jama, Palm, Buresh, Niang, Chacengo, Nzigubera dan Amadalo , 2000). Biomassa dari daun segar tithonia memiliki kandungan hara yang tinggi, sekitar $3,5 \% \mathrm{~N}$, $0.37 \% \mathrm{P}, 4,1 \% \mathrm{~K}, 0,59 \% \mathrm{Ca}$ dan $0,27 \% \mathrm{Mg}$ dari berat kering. Penyebab tingginya akumulasi hara tersebut belum begitu dipahami. Salah satu alasan yang cukup rasional adalah karena tithonia memiliki perakaran yang dalam dan terinfeksi endo maupun ektomikoriza disamping itu juga mampu mengeluarkan asam sitrat ke sekitar zona perakarannnya, sehingga melarutkan beberapa unsur hara tanah (Sanchez dan Jama, 2000).

Tanaman ini banyak ditemui dan tumbuh secara liar dalam jumlah besar di pinggiran jalan raya pada banyak tempat di Sumatra Barat (Hakim dan Agustian 2003). Beberapa hasil penelitian pendahuluan menunjukkan bahwa penggunaan tithonia mensubstitusikan penggunaan pupuk buatan $\mathrm{N}$ dan K sebanyak $25-50 \%$ untuk tanaman jagung (Fidorova, 2003), tanaman cabai (Novalina, 2003) dan tanaman jahe (Hakim dan Agustian, 2003).

Tanaman Chromolaena odorata (C. odorata) atau krinyuh selama ini hanyalah merupakan gulma yang banyak tumbuh di tepi pekarangan ataupun sebagai pagar pada ladang pertanian, dan biasanya tanaman ini membentuk semak bersama pagar yang ada. Keunikan C. odorata mudah tumbuh dimana-mana, hingga pada tanah marginal dan kekurangan air dan mampu berkembang dengan cepat. Dari hasil penelitian Jamilah (2006) membuktikan C. odorata yang ditanam sebagai pagar dengan jarak antar pagar $5 \mathrm{~m}$, dalam budidaya lorong pada setiap 3 bulan pangkas mampu menghasilkan 4 ton bahan segar ha-1, atau setara 1,2 $\mathrm{t}$ bahan kering ha- ${ }^{-1}$, setara dengan $73 \mathrm{~kg}$ urea, $9,7 \mathrm{~kg} \mathrm{\textrm {SP } _ { 3 6 }}$ dan 84 $\mathrm{kg} \mathrm{KCl}$.
Penelitian tentang pengaruh intensitas pengolahan tanah yang disertai dengan pemberian bahan organik yang mudah tersedia di sekitar lahan usaha tani pada tanah berpasir yang rendah kemampuan dalam menahan air, kemantapan agregat dan miskin unsur hara belum banyak dilakukan.

Tujuan dari penelitian adalah untuk memiperoleh jawaban mengenai: 1) Perubahan status kesuburan fisika dan kimia tanah setelah pemberian berbagai sumber bahan organik sebagai mulsa dan pengolahan tanah konservasi 2) Jenis sumber mulsa yang terbaik untuk diaplikasikan di lapangan yang bertumpu kepada kemampuannya menyediaan unsur hara dan kemudahtersediaannya untuk digunakan di lapangan. (3) Tindakan pengolahan tanah terbaik pada budidaya tanaman jagung pada tanah Psamment yang berpedoman kepada usaha pengawetan tanah dan air.

\section{METODE PENELITIAN}

Penelitian ini terdiri dari percobaan lapangan dan analisis tanah di laboratorium. Percobaan lapang telah dilaksanakan di Korong Olo Bangau, Kecamatan Batang Anai Kab.Padang Pariaman, sedangkan analisis tanah dilakukan di laboratorium Jurusan Tanah Fakultas Pertanian Unand. Penelitian ini berlangsung dari April sampai Oktober 2009. Percobaan dirancang menurut rancangan faktorial yang disusun dalam bentuk Rancangan Acak Kelompok (RAK) dengan 3 ulangan. Faktor I adalah tindakan pengolahan tanah $(\mathrm{T})$ yang terdiri dari: $\mathrm{N}_{\mathrm{t}}=$ Tanpa Olah Tanah, $\mathrm{M}_{\mathrm{t}}=$ Pengolahan Tanah minimum (dalam barisan tanam), $\mathrm{C}_{\mathrm{t}}=$ Pengolahan Tanah Konvensional. Faktor II yaitu berbagai sumber bahan organik yang terdiri dari $: \mathrm{Z}$ $=$ Tanpa mulsa, $\mathrm{P}=$ Jerami padi 8 ton $/$ ha, $\mathrm{J}=$ Jerami Jagung 8 ton $/$ ha, $\mathrm{T}=$ Tithonia 8 ton $/$ ha, dan $\mathrm{K}=$ Krinyuh 8 ton $/$ ha. Data yang diperoleh akan dianalasisis dengan ANOVA dan dilanjutkan dengan uji BNT $5 \%$. Untuk melihat hubungan antara pengolahan tanah dan pemberian mulsa organik. 
Analisis sifat fisika dan kimia tanah awal dan setelah tanah diperlakukan (contoh tanah diambil setelah panen). Contoh tanah yang digunakan yaitu contoh tanah terganggu dan tanah utuh, contoh tanah utuh diambil dengan menggunakan ring sampel pada kedalaman $0-15 \mathrm{~cm}$, sedangkan contoh tanah terganggu diambil secara komposit. Analisis tanah meliputi: tekstur tanah, Corganik, penetapan bobot isi, penetapan total ruang pori, serta persen agregasi tanah (de Boodt dan de Leenher) dan ciri kimia (pH, N, P, K, dan KTK) tanah.

\section{HASIL DAN PEMBAHASAN}

\section{Hasil Analisis Tanah Awal}

Sifat fisika dan ciri kimia tanah awal yang dianalisis tersebut adalah : tekstur, berat volume (BV), Kandungan Bahan Organik (BO), Total Ruang Pori (TRP), Permiabilitas, persen Agregasi, pH
$\mathrm{H}_{2} \mathrm{O}, \mathrm{pH} \mathrm{KCl}, \mathrm{N}$ total, $\mathrm{P}$ tersedia, $\mathrm{K}$-dd, basa-basa, dan KTK tanah. Hasil analisis sifat fisika dan ciri kimia tanah awal pada lokasi percobaan disajikan pada Tabel 1 .

Dari Hasil analisis tanah awal terlihat bahwa tanah di lokasi penelitian tanah merupakan tanah bertekstur pasir dengan kandungan pasir, debu, dan liat masing-masing $76 \%, 17 \%$, dan $7 \%$ yang termasuk ke dalam tekstur pasir berlempung. Berat volume tanah tergolong tinggi (1.45\%vol), bahan organik rendah $(6.3 \%)$, total ruang pori rendah (42\% vol) dan agregasi $(38 \%)$ rendah, dan permeabilitas tanah sangat cepat (34.2\%). Ciri kimia tanah tanah penelitian umumnya berada pada kriteria rendah sampai tinggi, dengan $\mathrm{pH}$ $\mathrm{H}_{2} \mathrm{O} 6.02$ (agak masam), C organik 3.65\%, $\mathrm{N}$ total $0.16 \%$ (rendah), $\mathrm{P}$ tersedia $23.9 \mathrm{ppm}$ (sedang), K-dd $0.44 \mathrm{me} / 100 \mathrm{~g}$ tanah (sedang), dan KTK $11 \mathrm{me} / 100 \mathrm{~g}$ tanah (rendah).

Tabel 1: Sifat fisika dan ciri kimia tanah tanah Psamment Korong Olo Bangau, Kecamatan Batang Anai Kabupaten Padang Pariaman

\begin{tabular}{lcl}
\hline \multicolumn{1}{c}{ Parameter } & Nilai & \\
\hline $\begin{array}{l}\text { Sifat Fisika Tanah } \\
\text { - Tekstur }\end{array} \quad$ & \\
$\quad$ Pasir (\%) & 76 & \\
$\quad$ Debu (\%) & 17 & \\
$\quad$ Liat $(\%)$ & 7.45 & tinggi \\
- Berat Volume $\left(\mathrm{g} \mathrm{cm}^{-3}\right)$ & 6.3 & sedang \\
- Bahan Organik $(\%)$ & 42.44 & rendah \\
- Total Ruang Pori $(\% \mathrm{v} / \mathrm{v})$ & & \\
& 38.04 & rendah \\
- Agregasi $(\%)$ & 34.2 & sangat cepat \\
- Permiabilitas (cm/jam) & & \\
& & \\
Ciri Kimia Tanah & 6.02 & agak masam \\
- pH (H2O) & 5.2 & \\
- pH KCl & 3.65 & tinggi \\
- C organik (\%) & 0.16 & rendah \\
- N total $(\%)$ & 22.8 & tinggi \\
- Ratio C/N & 23.9 & Sangat tinggi \\
- P tersedia (ppm) & 0.16 & sangat rendah \\
- Ca-dd (me/100g) & 0.27 & sangat rendah \\
- Mg-dd (me/100g) & 0.44 & sedang \\
- K-dd (me/100g) & 0.82 & tinggi \\
- Na-dd (me/100g) & 11.30 & rendah \\
- KTK (me/100g) &
\end{tabular}

*) Lembaga Penelitian Tanah (LPT) Bogor, 2005 
Hasil analisis tanah seperti yang disajikan pada Tabel 1 menunjukkan bahwa tanah Psamment yang digunakan mempunyai sifat fisika tanah yang kurang baik serta tingkat kesuburan yang rendah.

\section{Kelembaban Tanah}

Untuk mengetahui perbedaan kelembaban tanah akibat perlakuan pengolahan tanah dan pemberian mulsa, dilakukan pengukuran kelembaban tanahnya Pengukuran ini dilakukan setiap minggu mulai minggu pertama sampai minggu ke enam setelah tanam (MST). Hasil Pengukuran kelembaban tanah pada minggu ke empat sertelah diperlakukan (22/06/2009) disajikan pada Gambar 2.

Hasil pengukuran kelembaban tanah yang dilakukan pada minggu ke 4 setelah diperlakukan dengan mulsa (Gambar 2) menunjukkan bahwa kelembaban tanahnya sangat bervariasi. terlihat dengan jelas bahwa mulsa mampu mempertahankan kelembaban tanah yang lebih tinggi.

Kelembaban yang lebih tinggi dicapai pada tanah yang tidak diolah tetapi diberi mulsa. Kelembaban tertinggi terdapat pada kombinasi perlakuan tanpa olah tanah yang diberi mulsa jerami padi (Nt P) yaitu $27.97 \%$ dan kombinasi perlakuan tanpa olah tanah yang diberi mulsa jerami jagung (Nt J) yaitu $24.83 \%$, sedangkan pada perlakuan pengolahan tanah yang tidak diikuti dengan pemberian mulsa menyebabkan kelembaban tanah tidak bisa diperetahankan. Gambar 7 menuunjukkan bahwa kelembaban yang rendah terjadi pada perlakuan pengolahan tanpa pemberian mulsa, baik tanpa olah tanah (Nt Z: 12.24\%), olah tanah minimum (Mt Z; 10.67\%), maupun olah tanah konvensional (Ct Z; $12.3 \%$ ). Jika dibandingkan antara kelembaban tanah tertinggi (Nt P) dengan yang terendah (Mt Z) maka penggunaan mulsa dapat meningkatkan kelembaban sekitar $11 \%$.

$\begin{array}{rrrr}\text { Di } & \text { antara } & \text { berbagai } & \text { mulsa yang } \\ \text { diberikan } & \text { juga } & \text { terjadi } & \text { perbedaan }\end{array}$ kelembaban, kelembaban yang lebih tinggi diperoleh dengan pemberian mulsa jerami padi, diikuti oleh jagung, krinyuh, dan thitonia. Terjadinya hal tersebut karena diantara empat jenis mulsa yang digunakan mulsa jerami padi dan jerami jagung memberikan persen penutupan yang lebih tinggi serta lebih tahan terhadap pelapukan, sehingga mampu menjaga kelembaban tanah yang lebih baik dibandingkan dengan hijauan thitonia dan hijauan krinyuh. Hasil yang diperoleh ini ini sejalan dengan hasil penelitian Trong Thi, 1989 (cit. Suria Dikarta et al., 2002) yang mendapatkan bahwa pemberian mulsa Stylosanthes gracilis dapat mreningkatkan kelembaban

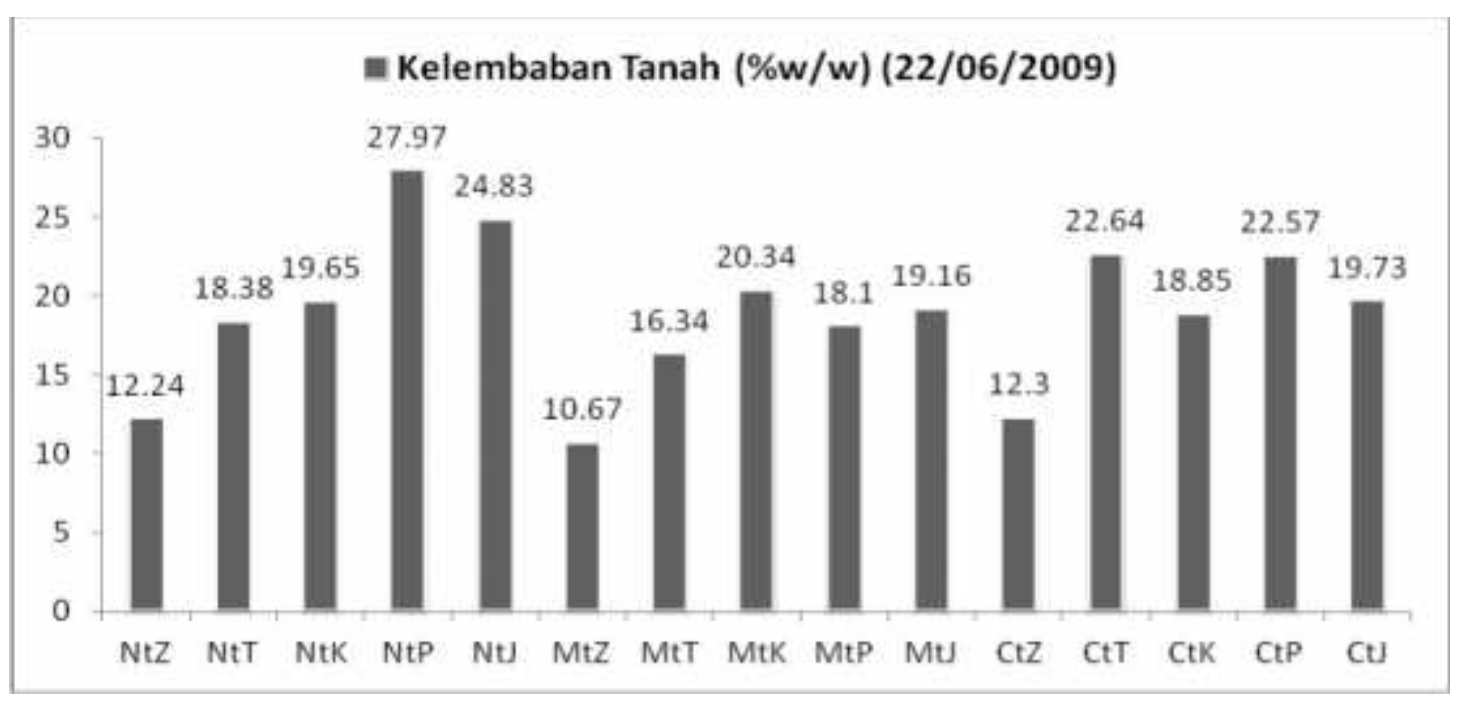

Gambar 1. Kelambaban tanah pada berbagai perlakuan Pengolahan Tanah dan Mulsa organik 4 minggu setelah tanah diperlakukan. 
tanah 3-6\%, serta hasil penelitian Adrinal (1997) bahwa pemberian mulsa jerami padi mampu menekan kehilangan air

Hasil penetapan berat volume tanah pada berbagai perlakuan pengolahan tanah dan mulsa organik disajikan pada Tabel 2. Hasil analisis sidik ragam menunjukkan terdapat interaksi antara pengolahan tanah dengan pemberian mulsa terhadap berat volume tanah psamment. Terdapatnya interaksi antara dua faktor perlakuan yang diberikan tersebut menunjukkan bahwa tindakan pengolahan tanah dan pemberian berbagai jenis mulsa memberikan pengaruh yang tidak sama terhadap berat volume tanah Psamment.

Tabel 2 menunjukkan bahwa BV tanah tertinggi umumnya terdapat pada kombinasi pemberian mulsa dengan tanah yang tidak diolah $(\mathrm{Nt})$ dengan nilai $\mathrm{BV}$ tertinggi yaitu $1.51 \mathrm{~g} / \mathrm{cm} 3$ terdapat pada dipermukaan tanah pada bididaya jagung di tanah berliat berat (vertisol).

Berat Volume Tanah

kombinasi perlakuan pengolahan tanpa pengolahan tanah dan tanpa pemberian mulsa (Nt Z) dan kombinasi perlakuan pengolahan tanpa pengolahan tanah dengan jerami padi (Nt J), sedangkan BV terendah didapatkan pada pengolahan tanah yang intensif (konvensional) yang dibarengi dengan pemberian mulsa. Nilai BV terendah yaitu pada pengolahan tanah konvensional dengan pemberian mulsa Krinyuh yaitu $1.26 \mathrm{~g} / \mathrm{cm} 3$.

Kandungan Bahan Organik Tanah

Hasil penetapan kandungan bahan organik tanah pada berbagai perlakuan pengolahan tanah dan mulsa organik disajikan pada Tabel 3.

Tabel 2. Pengaruh pengolahan tanah dan mulsa organik terhadap Berat Volume tanah Psamment

\begin{tabular}{|c|c|c|c|}
\hline \multirow{2}{*}{ Mulsa } & \multicolumn{3}{|c|}{ Pengolahan Tanah } \\
\hline & Tanpa (Nt) & Minimum (Mt) & Konvensional $(\mathrm{Ct})$ \\
\hline & . & $\mathrm{BO}(\%)$ & \\
\hline Tanpa (Z) & $1.51 \mathrm{a} \mathrm{A}$ & $1.45 \mathrm{aA}$ & $1.32 \mathrm{bA}$ \\
\hline Thitonia (T) & $1.38 \mathrm{aA}$ & $1.39 \mathrm{aA}$ & $1.36 \mathrm{aA}$ \\
\hline Krinyuh (K) & $1.50 \mathrm{aA}$ & $1.50 \mathrm{aA}$ & $1.26 \mathrm{bB}$ \\
\hline Jerami Padi (P) & $1.39 \mathrm{aA}$ & $1.46 \mathrm{aA}$ & $1.41 \mathrm{aA}$ \\
\hline Jerami Jagung (J) & $1.51 \mathrm{aA}$ & $1.42 \mathrm{aA}$ & $1.46 \mathrm{aA}$ \\
\hline
\end{tabular}

Angka-angka yang diikuti oleh huruf besar yang sama pada setiap kolom dan oleh huruf kecil yang sama pada setiap baris berbeda tidak nyata menurut BNT (0.05)

Tabel 3. Pengaruh pengolahan tanah dan mulsa organik terhadap kandungan bahan organik tanah Psamment

\begin{tabular}{|c|c|c|c|}
\hline \multirow{2}{*}{ Mulsa } & \multicolumn{3}{|c|}{ Pengolahan Tanah } \\
\hline & Tanpa (Nt) & Minimum (Mt) & Konvensional $(\mathrm{Ct})$ \\
\hline & & $\mathrm{BO}(\%) \ldots$. & $\ldots$ \\
\hline Tanpa (Z) & $6.52 \mathrm{~A} \mathrm{a}$ & $6.53 \mathrm{~A} \mathrm{a}$ & $6.61 \mathrm{~B} \mathrm{a}$ \\
\hline Thitonia (T) & $6.53 \mathrm{~A} \mathrm{~b}$ & $6.66 \mathrm{~A} \mathrm{~b}$ & $8.10 \mathrm{~A} \mathrm{a}$ \\
\hline Krinyuh $(\mathrm{K})$ & $6.81 \mathrm{~A} \mathrm{a}$ & $6.82 \mathrm{~A} \mathrm{a}$ & $7.03 \mathrm{~A} \mathrm{a}$ \\
\hline Jerami Padi $(\mathrm{P})$ & $7.25 \mathrm{~A}$ ab & $6.64 \mathrm{~A} \mathrm{~b}$ & $8.30 \mathrm{~A} \mathrm{a}$ \\
\hline Jerami Jagung (J) & $6.81 \mathrm{~A} \mathrm{a}$ & $6.81 \mathrm{~A} \mathrm{a}$ & $7.84 \mathrm{~A} \mathrm{a}$ \\
\hline & & & \\
\hline
\end{tabular}

Angka-angka yang diikuti oleh huruf besar yang sama pada setiap kolom dan huruf kecil yang sama pada setiap baris berbeda tidak nyata menurut BNT (0.05). 
Hasil analisis sidik ragam menunjukkan adanya interaksi antara pengolahan tanah dengan pemberian mulsa organik terhadap kandungan bahan organik tanah. Terdapatnya interaksi antara dua faktor perlakuan yang diberikan tersebut menunjukkan bahwa berbagai jenis mulsa memberikan pengaruh yang tidak sama terhadap kandungan bahan organik tanah pada ketiga bentuk pengolahan tanah.

Tabel 3 menunjukkan bahwa secara umum kandungan bahan organik terendah ditermukan pada tindakan tanpa pemberian mulsa (Nt Z, Mt Z, dan $\mathrm{Ct}$ Z) dan meningkat seiring dengan pemberian berbagai jenis mulsa. Kandungan bahan organik tertinggi terdapat pada kombinasi perlakuan pengolahan konvensional dengan Thitonia (Ct T) yaitu $8.30 \%$ dan yang terendah pada kombinasi tanpa olah tanah dan tanpa mulsa (Nt Z) yaitu 6.52\%. Dari data di atas dapat dijelaskan bahwa mulsa organik merupakan sumber bahan organik yang dapat digunakaan untuk mempertahankan dan meningkatkan kandungan bahan organik tanah Psamment.

\section{Total Ruang Pori}

Hasil penetapan total ruang pori tanah pada berbagai perlakuan pengolahan tanah dan mulsa organik disajikan pada Tabel 4.
Hasill analisis sidik ragam menunjukkan adanya interaksi antara pengolahan tanah dengan pemberian mulsa organik terhadap total ruang pori tanah. Tabel 4 menunjukkan bahwa total ruang pori tertinggi terdapat pada kombinasi perlakuan pengolahan tanah konvensional dan hijauan Krinyuh (Ct K) yaitu $49.7 \%$ vol dan yang terendah pada kombinasi tanpa olah tanah dengan tanpa pembrian mulsa (Nt Z), dan kombinasi antara tanpa pengolahan tanah dengan pembeirian krinyuh( Nt K) yaitu $40.2 \%$ vol.

Meningkatnya total ruang pori tanah pada tanah yang diperlakukan dengan pengolahan tanah dan mulsa organik. Pengolahan tanah menyebabkan menurunnya kepadatan tanah, sementara bahan organik merupakan salah satu faktur yang dapat meningkatkan kegemburan tanah. Dari data total ruang pori tanah yang disajikan pada tabel 4 dapat disimpulkan bahwa pengolahan tanah yang disertai pemberian bahan organik sebagai mulsa mampu menjaga kegemburan tanah psamment untuk tidak segera kembali memadat, karena mulsa yang diberikan selain mampu berfungsi untuk melindungi tanah dari proses pemadatan juga menggemburkan tanah. Keadaan ini sangat menguntungkan untuk kondisi perakaran tanaman.

Tabel 4. Pengaruh pengolahan tanah dan mulsa organik terhadap total ruang pori tanah Psamment

\begin{tabular}{|c|c|c|c|}
\hline \multirow{2}{*}{ Mulsa } & \multicolumn{3}{|c|}{ Pengolahan Tanah } \\
\hline & Tanpa (Nt) & Minimum (Mt) & Konvensional $(\mathrm{Ct})$ \\
\hline & \multicolumn{3}{|c|}{ 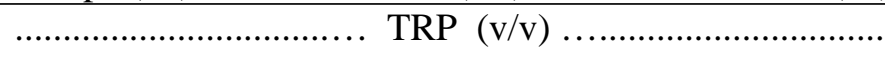 } \\
\hline Tanpa (Z) & $40.2 \mathrm{~b} \mathrm{~B}$ & $42.3 \mathrm{ab} \mathrm{A}$ & 47.5 a $\mathrm{AB}$ \\
\hline Thitonia (T) & $45.0 \mathrm{a} \mathrm{A}$ & 44.8 a $\mathrm{A}$ & 44.9 a $\mathrm{AB}$ \\
\hline Krinyuh (K) & 40.2 a B & 40.2 a $\mathrm{A}$ & 49.7 b A \\
\hline Jerami Padi (P) & 44.6 a $\mathrm{A}$ & 42.1 a $\mathrm{A}$ & 43.3 a B \\
\hline Jerami Jagung (J) & 40.4 a B & 43.6 a $\mathrm{A}$ & 41.2 a B \\
\hline
\end{tabular}

$\mathrm{KK}=11.16 \%$

Angka-angka yang diikuti oleh huruf besar yang sama pada setiap kolom dan huruf kecil yang sama pada setiap baris berbeda tidak nyata menurut BNT (0.05) 
Agregasi Tanah

Hasil penetapan Agregasi Tanah pada berbagai perlakuan pengolahan tanah dan mulsa organik disajikan pada Tabel 5. Hasil analisis sidik ragam menunjukkan adanya interaksi antara pengolahan tanah dengan pemberian mulsa organik terhadap persen agregasi tanah. Tabel 5 menunjukkan bahwa persen agregasi tertinggi terdapat pada kombinasi perlakuan pengolahan tanah minimum dan jerami Padi (Mt P) yaitu 55.9\% dan yang terendah pada kombinasi tanpa olah tanah dengan thitonia(Nt $\mathrm{T})$ yaitu $34.6 \%$. Meningkatnya agregasi tanah berhubungan dengan meningkatnya kandungan bahan organik tanah dari tanah yang diperlakukan. Meningkatnya kandungan bahan organik akan menghasilkan bahan-bahan yang berfungsi sebagai perekat dalam pembentukan agregat tanah. Penambahan bahan organik ke dalam tanah juga dapat membentuk struktur tanah yang baik, agregat tanah yang lebih mantap dan tanah lebih tahan terhadap pengaruh dari luar. Pemberian bahan organik kepada tanah berpasir (Psamment) secara bertahap ternyata mampu meningkatkan proses agregasi yang memang sangat lambat terjadi pada tanah berpasir karena tidak adanya bahan perekat dan juga tidak mempunyai liat aktif yang sangat diperlukan sebagai agen pengagregasi tanah. Tabel 5 memperlihatkan secara jelas terjadinya proses pengagregasian tersebut. Hal ini diantaranya dengan adanya kontribusi dari bahan organik yang semakin meningkat (Tabel 3).

Tabel 5. Pengaruh pengolahan tanah dan mulsa organik terhadap persen agregasi tanah Psamment

\begin{tabular}{|c|c|c|c|}
\hline \multirow{2}{*}{ Mulsa } & \multicolumn{3}{|c|}{ Pengolahan Tanah } \\
\hline & Tanpa (Nt) & Minimum (Mt) & Konvensional $(\mathrm{Ct})$ \\
\hline & \multicolumn{3}{|c|}{...Agregasi $(\%)$} \\
\hline Tanpa (Z) & $45.4 \mathrm{ab} \mathrm{A}$ & $48.4 \mathrm{ab} \mathrm{AB}$ & $45.4 \mathrm{ab} \mathrm{A}$ \\
\hline Thitonia (T) & $34.6 \mathrm{~b} \mathrm{~B}$ & $44.8 \mathrm{ab} B$ & $49.7 \mathrm{ab} \mathrm{AB}$ \\
\hline Krinyuh (K) & $45.1 \mathrm{ab} A$ & $43.0 \mathrm{~b} \quad \mathrm{~B}$ & $43.4 \mathrm{~b} \quad \mathrm{~A}$ \\
\hline Jerami Padi (P) & $47.3 \mathrm{a} \mathrm{A}$ & 55.9 a A & $54.1 \mathrm{a} \quad \mathrm{A}$ \\
\hline Jerami Jagung (J) & $44.1 \mathrm{a} \quad \mathrm{A}$ & $47.5 \mathrm{a} \quad \mathrm{AB}$ & $49.3 \mathrm{a} \quad \mathrm{AB}$ \\
\hline \multicolumn{4}{|c|}{$\mathrm{KK}=15.56 \%$} \\
\hline
\end{tabular}

Angka-angka yang diikuti oleh huruf besar yang sama pada setiap kolom dan huruf kecil yang sama pada setiap baris berbeda tidak nyata menurut BNT (0.05)

\section{Ciri Kimia Tanah}

Hasil analisis ciri kimia tanah setelah perlakuan yang terdiri dari $\mathrm{pH}$ $\left(\mathrm{H}_{2} \mathrm{O} ; \mathrm{KCl}\right), \mathrm{N}$ total, $\mathrm{P}$ tersedia, dan $\mathrm{K}$-dd dan KTK disajikan pada Tabel 6. Dari data ciri kimia tanah yang ditampilkan terlihat bahwa pemberian mulsa organik mampu memperbaiki kondisi hara tanah Psamment. Pengaplikasian berbagai jenis mulsa mampu menurunkan kemasaman tanah $\left(\mathrm{pH} \mathrm{H}_{2} \mathrm{O}\right)$, meningkatkan kandungan $\mathrm{P}$ tersedia, dan $\mathrm{K}$ dd tanah Psamment. Tanah yang diperlakukan dengan pengolahan tanah dan pemberian mulsa memperlihatkan kondisi kesuburan tanah yang lebih baik. pH H2O tertinggi terdapat pada kombinasi perlakuan pengolahan tanah minimum dan pemberian mulsa jerami padi (Mt P) yaitu 6.45, dan $\mathrm{pH}$ $\mathrm{H} 2 \mathrm{O}$ terendah pada kombinasi perlakuan tanpa olah tanah dan tanpa mulsa (Nt Z) yaitu 5.72.

$\mathrm{P}$ tersedia tanah juga meningkat dibandingkan dengan $\mathrm{P}$ tersedia tanah sebelum perlakuan. $\mathrm{P}$ tersedia tertinggi ditemukan pada kombinasi perlakuan pengolahan tanah konvensional dan pemberian mulsa jagung (Ct J). Semakin baiknya kondisi hara tanah tanah terutama $\mathrm{P}$ tersedia ini diduga karena meningkatnya $\mathrm{pH}$ tanahnya, disamping itu $\mathrm{P}$ yang relatif tinggi disebabkan karena lahan yang digunakan sebelumnya adalah lahan yang sudah digunakan secara intensif untuk 
tanaman semusim seperti jagung dan semangka, dengan menggunakan pupukpupuk buatan.

Tabel 6. Hasil penetapan beberapa ciri kimia tanah Psamment akibat perklakuan pengolahan tanah dan pemberian mulsa organik

\begin{tabular}{|c|c|c|c|}
\hline \multirow{2}{*}{ Mulsa } & \multicolumn{3}{|c|}{ Pengolahan Tanah } \\
\hline & Tanpa (Nt) & Minimum (Mt) & Konvensional $(\mathrm{Ct})$ \\
\hline & & $\mathrm{pH} \mathrm{H}_{2} \mathrm{O}(1: 1)$ & \\
\hline Tanpa (Z) & $5.72 \mathrm{am}$ & $5.95 \mathrm{am}$ & $5.99 \mathrm{am}$ \\
\hline Thitonia $(\mathrm{T})$ & $6.06 \mathrm{am}$ & $6.08 \mathrm{am}$ & $5.78 \mathrm{am}$ \\
\hline Krinyuh (K) & $5.89 \mathrm{am}$ & $5.94 \mathrm{am}$ & $5.93 \mathrm{am}$ \\
\hline Jerami Padi (P) & $5.92 \mathrm{am}$ & $6.46 \mathrm{am}$ & $6.24 \mathrm{am}$ \\
\hline \multirow[t]{2}{*}{ Jerami Jagung (J) } & $6.02 \mathrm{am}$ & $6.13 \mathrm{am}$ & $6.10 \mathrm{am}$ \\
\hline & & $\mathrm{pH} \quad \mathrm{KCl}(1: 1$ & …… \\
\hline Tanpa (Z) & 5.57 & 5.65 & 5.65 \\
\hline Thitonia (T) & 5.66 & 5.70 & 5.51 \\
\hline Krinyuh $(\mathrm{K})$ & 5.64 & 5.50 & 5.65 \\
\hline Jerami Padi (P) & 5.59 & 5.87 & 5.74 \\
\hline \multirow[t]{2}{*}{ Jerami Jagung (J) } & 5.51 & 5.74 & 5.70 \\
\hline & & P tersedia $(\mathrm{ppm})$ & ..................... \\
\hline Tanpa (Z) & $21.26 \mathrm{st}$ & $19.09 \mathrm{t}$ & $22.09 \mathrm{st}$ \\
\hline Thitonia (T) & $22.68 \mathrm{st}$ & $26.45 \mathrm{st}$ & $21.16 \mathrm{st}$ \\
\hline Krinyuh $(\mathrm{K})$ & $22.62 \mathrm{st}$ & $23.54 \mathrm{st}$ & $17.84 \mathrm{t}$ \\
\hline Jerami Padi (P) & $21.85 \mathrm{st}$ & $22.19 \mathrm{st}$ & $29.73 \mathrm{st}$ \\
\hline \multirow[t]{2}{*}{ Jerami Jagung (J) } & $25.89 \mathrm{st}$ & $21.26 \mathrm{st}$ & $27.37 \mathrm{st}$ \\
\hline & & K-dd (me/100 & . \\
\hline Tanpa (Z) & $0.41 \mathrm{~s}$ & $0.42 \mathrm{~s}$ & $0.45 \mathrm{~s}$ \\
\hline Thitonia (T) & $0.54 \mathrm{~s}$ & $0.95 \mathrm{t}$ & $0.83 \mathrm{t}$ \\
\hline Krinyuh $(\mathrm{K})$ & $0.82 \mathrm{t}$ & $0.63 \mathrm{~s}$ & $0.84 \mathrm{t}$ \\
\hline Jerami Padi (P) & $0.76 \mathrm{t}$ & $0.95 \mathrm{t}$ & $1.00 \mathrm{t}$ \\
\hline Jerami Jagung (J) & $0.64 \mathrm{~s}$ & $0.51 \mathrm{~s}$ & $0.58 \mathrm{~s}$ \\
\hline
\end{tabular}

Keterangan : am = agak masam; $\mathrm{n}=$ netral; $\mathrm{r}=$ =rendah; $\mathrm{s}=$ sedang; $\mathrm{t}=$ tinggi; $\mathrm{st}=$ sangat tinggi

Kriteria : Balai Penelitian Tanah (BPT) Bogor, 2005

Dari Tabel 6 terlihat bahwa K-dd tanah setelah perlakuan bervariasi dari $0.41-1.00$ $\mathrm{me} / 100 \mathrm{~g}$ tanah. Data di atas menunjukkan bahwa pemberian mulsa mampu meningkatkan $\mathrm{K}$ dd tanah. Kdd tertinggi terdapat pada kombinasi perlakuan pengolahan tanah konvensional dengan jerami padi $(\mathrm{Ct} \mathrm{P})$ yaitu $1.00 \mathrm{me} / 100 \mathrm{~g}$ tanah, dikuti oleh Mt T, dan Mt P yaitu 0.95 me/100g tanah, sedangkan yang terendah dijumpai pada Nt Z. Meningkatnya K tanah ini bisa dipahami karena adanya kontribusi mulsa yang diberikan. Salah satu keuntungan pemberian mulsa adalah karena mulsa yang telah menngalami dekomposisi akan menyumbangkan hara kepada tanah terutama unsur kalium. Hasil penelitian ini sejalan dengan apa yang didapatkan oleh Gill dan Sri Adiningsih (1986) bahwa penggunaan alang-alang sebagai mulsa dapat mengefisienkan pemakaian pupuk $\mathrm{K}$ dan meningkatkan hasil jagung. 
Keragaan Tanaman

Tinggi Tanaman

Pengukuran terhadap tinggi tanaman dilakukan pada saat pertumbuhan awal pertumbuhan tanaman. Pengukuran tersebut dilakukan setiap minggu mulai dari minggu ke dua hingga minggu ke enam setelah tanam (MST). Hasil pengukuran tinggi tanaman pada minggu ke 4 (4 MST) disajikan pada Gambar 2.

\section{Tinggi Tanaman Jagung $(\mathrm{cm})$}

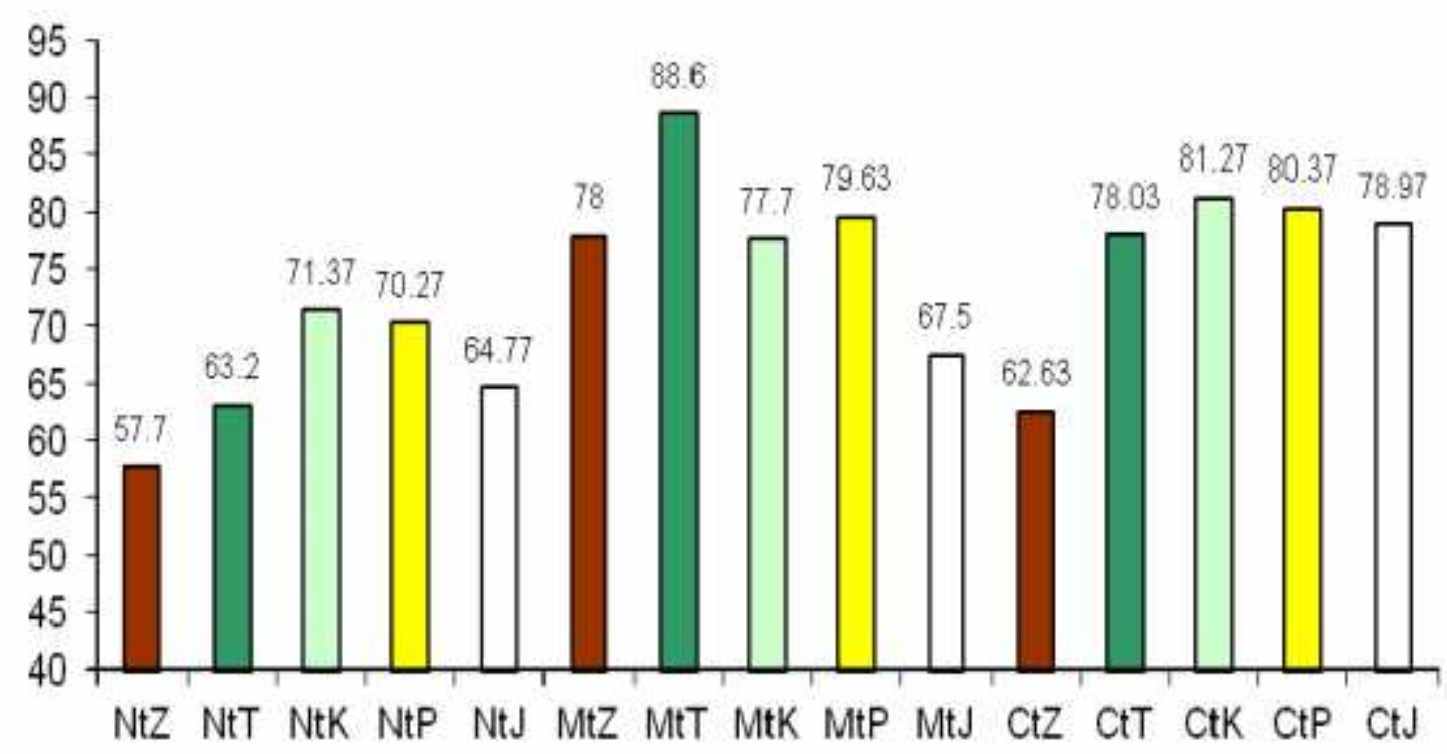

Gambar 2. Pertumbuhan tanaman jagung pada berbagai kombinasi perlakuan pengolahan tanah dan mulsa organik 4 Minggu Setelah Tanaman (MST)

Dari pengukuran tinggi tanaman pada minggu ke 4 setelah tanam terlihat bahwa tanaman yang ditanam pada tanah yang diperlakukan dengan mulsa memperlihatkan pertumbuhan vegetatif yang lebih baik dibandingkan dengan tanpa aplikasi mulsa. Tinggi tanaman tertinggi terdapat pada kombinasi perlakuan pengolahan tanah minimum dengan mulsa thitonia (Mt T) yaitu $88.6 \mathrm{~cm}$, kemudian diikuti oleh perlakuan pengolahan tanah konvensional dengan mulsa krinyuh $(\mathrm{Ct} \mathrm{K})$ yaitu $81.27 \mathrm{~cm}$, sedangkan tanaman yang terendah adalah pada perlakuan tanpa olah tanah dan tanpa pemberian mulsa (Nt Z) yaitu $57.7 \mathrm{~cm}$.
Pengamatan keragaan tanaman di lapang menunjukkan bahwa pada perlakuan pengolahan tanah tanpa diikuti pemberian mulsa pertumbuhan tanaman agak terhambat, kecuali pada pengolahan minimum (Mt Z) yang relatif lebih baik. Hal ini adalah karena dengan pengolahan minimum maka kehilangan air pada tanah berpasir ini dari lapisan perakaran tanaman lebih lambat dibandingkan dengan pengolahan yang intensif $(\mathrm{Ct} \mathrm{Z})$, sedangkan pada tanpa olah tanah (Nt Z) lebih berhubungan dengan kepadatan yang tinggi (Tabel 2) dan kandungan bahan organik yang rendah (Tabel 3).

Secara umum dapat disimpulkan bahwa lebih baiknya pertumbuhan ini 
disebabkan membaiknya kondisi fisika tanah dan ciri kimianya seperti kelembaban tanah yang lebih tinggi, menurunnya kepadatan tanah, kandungan bahan organik tanah meningkat, agregasi yang lebih baik, $\mathrm{P}, \mathrm{K}$, dan $\mathrm{pH}$ yang meningkat.

\section{Berat Pipilan Kering Jagung}

Berat pipilan kering jagung pada berbagai perlakuan pengolahan tanah dan mulsa organik disajikan pada Tabel 7 . Hasil Hasil analisis sidik ragam menunjukkan adanya interaksi yang nyata antara pengolahan tanah dan mulsa organik terhadap berat pipilan kering jagung. Secara umum terlihat bahwa hasil yang tringgi diperoleh pada perlakuan olah tanah minimum dengan pemberian mulsa organik (Mt T, Mt K, Mt P, dan Mt J), sedangkan hasil yang rendah didapat pada pengolahan tanah tanpa dibarengi pemberian mulsa $(\mathrm{Nt}$ $\mathrm{Z}$, Mt Z, dan $\mathrm{Ct} \mathrm{Z}$ ). Hasil tanaman tertinggi diperoleh pada kombinasi pengolahan tanah minimum dengan mulsa Thitonia (Mt T) yaitu $9.95 \mathrm{~kg} /$ plot, dikut berturut turut oleh, Ct T (9.45 kg/plot), Mt P $(9.20$ $\mathrm{kg} / \mathrm{plot})$, Mt $\mathrm{K}$ (9.08 kg/plot) Bila dibandingkan dengan hasil terendah (Nt Z; $6.08 \mathrm{~kg} / \mathrm{plot}$ ) berarti terjadi peningkatan hasil sebesar $63 \%$. Terjadinya peningkatan hasil tanaman ini berkaitan erat dengan perbaikan sifat fisika dan ciri kimia tanahnya akibat tindakan pengolahan tanah dan pemberian mulsa organik, seperti meningkatnya kelembaban tanah, kandungan bahan organik, agregasi, serta menurunnya tingkat kepadatan tanah.

Tabel 7. Pengaruh pengolahan tanah dan mulsa organik terhadap berat pipilan jagung pada tanah Psamment

\begin{tabular}{lccc}
\hline \multirow{2}{*}{ Mulsa } & \multicolumn{3}{c}{ Pengolahan Tanah } \\
\cline { 2 - 4 } & Tanpa (Nt) & Minimum (Mt) & Konvensional (Ct) \\
\hline \multirow{3}{c}{ Panpilan kering (kg/plot) } \\
Thitonia (T) & $6.08 \mathrm{aB}$ & $7.78 \mathrm{aBC}$ & $7.06 \mathrm{aBC}$ \\
Krinyuh (K) & $6.91 \mathrm{~b} \mathrm{AB}$ & $9.95 \mathrm{a} \mathrm{A}$ & $9.45 \mathrm{aA}$ \\
Jerami Padi (P) & $7.36 \mathrm{~b} \mathrm{~A}$ & $9.08 \mathrm{aBC}$ & $9.00 \mathrm{a} \mathrm{AB}$ \\
Jerami Jagung (J) & $6.77 \mathrm{bAB}$ & $9.20 \mathrm{aABC}$ & $8.20 \mathrm{ab} \mathrm{C}$ \\
\hline & $6.31 \mathrm{a} \mathrm{AB}$ & $7.29 \mathrm{abC}$ & $8.50 \mathrm{~b} \mathrm{C}$ \\
\hline
\end{tabular}

Angka-angka yang diikuti oleh huruf besar ang sama pada setiap kolom dan huruf kecil yang sama pada setiap baris berbeda tidak nyata menurut BNT (0.05)

\section{KESIMPULAN}

1. Penggunaan berbagaii mulsa organik (thitonia, krinyuh, jerami padi dan jerami jagung) mampu memperbaiki sifat fisika dan ciri kimia tanah Psamment

2. Pengolahan tanah minimum yang dikombinasikan dengan pemulsaan menciptakan kondisi yang optimum bagi pertumbuhan dan hasil tanaman jagung pada tanah Psamment.

3. Hasil tanaman jagung tertinggi diperoleh pada kombinasi perlakuan pengolahan tanah minimum (pengolahan tanah dalam barisan tanaman) dengan hijauan thitonia yaitu $9.95 \mathrm{~kg} /$ plot.

4. Berdasarkan kemampuannya untuk memperbaiki sifat fisika tanah dan kemudah tersediaannya di sekitar lahan usaha tani, jerami padi dan thitonia merupakan dua sumber mulsa yang dapat dipertimbangkan untuk digunakan dalam budidaya jagung pada tanah Psamment.

\section{DAFTAR PUSTAKA}

Adrinal dan N. Armon. 1993. Pengaruh berbagai cara pengolahan tanah dan pemberian mulsa terhadap penyebaran pori tanah Vertisol dan hasil jagung. Jurnal Penelitian Unand. No. 16/Mei/tahun VI/1994. Hal.132 -142.

Adrinal dan N. Armon. 1997 Besarnya kehilangan air anah akibat pemberian 
mulsa jerami padi dan pengolahan tanah pada vertisol yang ditanami jagung. Jurnal Teknologi Pertanian Andalas Vo1.02, No.3, Juli 1997.

Agustamar, 2000. Pengaruh bahan organik dan takaran $\mathrm{N}$, P, dan $\mathrm{K}$ terhadap serapan hara dan pertumbuhan tanaman pisang raja sereh dan cavendish di lahan kritis. Tesis S2 PPS Univ. Andalas. Padang. 96 hal.

Brown, R.E, J.L.Havlin, D.J. Lyons, C.R. Fenster, and G.A. Peterson. 1991. Longterm tillage and nitrogen effects on wheat production in a wheat fallow rotation. p 326. In agronomy abstracts. Annual meeting ASA, CSSA, Denver Colorado, Oct 27- Nov 1, 1991.

Dariah, A. 2007. Konservasi tanah pada lahan tegalan. Dalam Agus. F et. al, (eds) Bunga rampai Konservasi tanah dan Air. Hal. 138144. Pengurus Pusat Masyarakat Konservasi tanah dan Air Indonesia 2004-2007. Jakarta.

Fidorova, Y. 2003. Substitusi N-urea dengan NTithonia (tithonia diversivolia) untuk tanaman jagung pada Ultisol. Skripsi Sarjana Pertanian unand. Padang.

Gill, D.W and J. Sri Adiningsih. 1986. Responses of land rice and soybean to potassium fertilization and residu management and green manuring in Sitiung, West Sumatera. Pemberitaan Penelitian Tanah dan Pupuk No.6:26-31.

Hakim, N dan Agustian. 2003. Gulma thitonia dan pemanfaatannya sebagai sumber bahan organik dan unsur hara untuk tanaman hortikultura. Laporan hibah bersaing XI/I. Tahun anggaran 2003. Unand. 62 hal.

Jama.B.A., C.A. Palm., R.J.Buresh., A. I. Niang., C. Gachego., G. Nziquheba and B.Amadado. 2000. Tithonia Diversifolia as a green manure for improvement of soil fertility in western Kenya. A Review.Agroforestry Systems

Jamilah. 2006. Substitution N fertilizer by greean manure to maize, given rock phosphate and vesicular arbuscular mycorrhiza on typic paleudult. Jurnal Akademika Bidang eksata Vol. 10 no. 2 : $1-11$

Novalina. 2003. Substitusi NK pupuk buatan dengan NK Tithonia diversifolia untuk tanaman cabai (Capsicum annum L) padaUltisol. Skripsi Sarjana Pertanian Unand. Padang.

Sanchez, P. A. and B. A. Jama. 2000. Soil fertility replenishment takes off in East sand Southern Africa. International Symposium on Balanched Nutrient Management System for The Moist Savanna and Forest Zones of Africa. Held on 9 October 2000 in Benin. Africa.

Suriadikarta, T. Prihatini, D. Setyorini, W. Hartatik. 2002. Teknologi penegelolaan bahan organik tanah. dalam. Adimihardja, A et. al (eds) Teknologi Pengelolaan Lahan kering. Pusat Penelitian dan Pengembangan tanah dan Agroklimat. BPPT Deptan. Bogor.hal 183-238.

Suwardjo. 1981. Peranan sisa tanaman dalam konservasi tanah dan air pada lahan usaha tani tanaman semusim. Disertasi Doktor pada Fakultas Pasca Sarjana IPB. Bogor. 240 hal.

Wagger, M.G., and H.P. Denton. 1991. Consequences of continuous and alternating tillage regimes on residue cover and grain yield in a corn-soybean rotation p. 344. In agronomy abstracts. Annual meeting ASA, CSSA, Denver Colorado, Oct 27- Nov 1, 1991. 